\title{
Impact of introduced seastars Asterias amurensis on survivorship of juvenile commercial bivalves Fulvia tenuicostata
}

\author{
D. Jeff Ross ${ }^{1,2, *}$, Craig R. Johnson ${ }^{1}$, Chad L. Hewitt ${ }^{2}$ \\ ${ }^{1}$ School of Zoology, University of Tasmania, GPO Box 252-05, Sandy Bay, Tasmania 7001, Australia \\ ${ }^{2}$ Centre for Research on Introduced Marine Pests, CSIRO Marine Research, GPO Box 1538, Hobart, Tasmania 7001, Australia
}

\begin{abstract}
The introduction and establishment of the predatory seastar Asterias amurensis in southern Australia is considered a major threat to benthic marine communities and commercial bivalves. The impact of $A$. amurensis on a soft sediment assemblage in SE Tasmania was quantified, with particular attention to effects of seastar predation on the survivorship of recently settled juveniles of the commercial bivalve Fulvia tenuicostata. In a manipulative experiment, densities of $F$. tenuicostata juveniles were reduced by ca. 15 fold (from 580 to $35 \mathrm{~m}^{-2}$ ) in the presence of seastars at background densities relative to the treatment without seastars. In a feeding survey, A. amurensis exhibited preference for $F$. tenuicostata following settlement of the bivalve over the period from December 1997 to January 1998, which comprised 80 and 50\% of the seastar's stomach items in February 1998 and April 1998, respectively. However, A. amurensis preferred a variety of other prey taxa when the abundance of $F$. tenuicostata was low, particularly other bivalves, gastropods and the echinoid Echinocardium cordatum. This indicates that the seastar may potentially affect the abundance of other prey taxa. The results provide further support to the hypothesis that predation by A. amurensis is largely responsible for the recent decline and subsequent rarity of large bivalves in its current distribution in Tasmania. The potential of seastar predation to have wider ecosystem level effects than the short-term direct effects reported here is a major concern.
\end{abstract}

KEY WORDS: Seastar · Introduced species $\cdot$ Predation $\cdot$ Impacts $\cdot$ Bivalves $\cdot$ Soft sediment $\cdot$ Asterias amurensis

Resale or republication not permitted without written consent of the publisher

\section{INTRODUCTION}

In the late 20th century, there has been a rapid acceleration of biological introductions due to human-aided movement of species across and between continents (Carlton \& Geller 1993, Lodge 1993, Mills et al. 1993, Vitousek 1994, Cohen \& Carlton 1998, Ruiz et al. 2000). Introduced species most likely to have a large impact on native communities are those of predators (Elton

${ }^{*}$ Present address: Department of Zoology, University of Melbourne, Melbourne, Victoria 3010, Australia.

E-mail: rossdj@unimelb.edu.au
1958, Lodge 1993, Lafferty \& Kuris 1994) and members of Asteroidea are among the most important predators in marine benthic systems (Menge 1982). In Australia, the introduced northern Pacific seastar Asterias amurensis has been highly conspicuous as a voracious generalist predator in soft-sediment habitats (Grannum et al. 1996). It was first recorded in SE Tasmania in 1986 (Buttermore et al. 1994, Byrne et al. 1997) where it has become the dominant invertebrate predator in the Derwent Estuary (Grannum et al. 1996), but now also occurs at high densities in Port Phillip Bay on mainland Australia. Although other invertebrate predators are present in the Derwent Estuary, such as the native seastar Coscinasterias muricata, none of them attain 
comparable densities to $A$. amurensis, particularly over such large areas and for consistently long periods. Densities of the seastar recorded within the estuary (up to $46 \mathrm{~m}^{-2}$; S. Ling unpubl. data) are far greater than any recorded during outbreaks of the species in the Ariake Sea, Japan (Nojima et al. 1986).

The key role of asteroid predation as a structuring force in benthic communities largely reflects their ability to exploit a wide range of food resources and habitats (Menge 1982). Asterias species, such as A. amurensis, are renowned for their capacity to form massive aggregations and cause enormous damage to shellfish grounds (reviewed by Sloan 1980). In its native range, A. amurensis causes considerable damage to commercial shellfisheries (e.g. oysters, cockles, scallops, other clams; Hatanaka \& Kosaka 1959, Kim 1969, Nojima et al. 1986). Additionally, it is an opportunistic feeder on a variety of epifaunal and infaunal species including molluscs, ascidians, bryzoans, sponges, crustaceans, polychaetes, fish and echinoderms (Hatanaka \& Kosaka 1959, Fukuyama \& Oliver 1985, Fukuyama 1994). On this evidence alone, it has been anticipated that the successful establishment of $A$. amurensis in SE Tasmania has the potential to profoundly affect native benthic marine communities and commercial species, particularly bivalves (Lockhart 1995, Grannum et al. 1996).

In contrast to the extensive research on introduced species in freshwater and terrestrial communities, the impacts of introduced species on native communities in marine and estuarine habitats have been quantified in only a handful of studies (e.g. Race 1982, Brenchley \& Carlton 1983, Nichols et al. 1990, Lambert et al. 1992, Posey et al. 1993, Grosholz \& Ruiz 1995, Grosholz et al. 2000, Ross et al. in press). In Tasmania, indirect indications of impact from observations of seastar foraging behaviour, stomach contents and estimates of feeding electivity suggest the potential for considerable impact of Asterias amurensis on native species, particularly bivalves (Morrice 1995, Grannum et al. 1996, Lockhart \& Ritz 2001). Furthermore, live bivalves $>5$ to $10 \mathrm{~mm}$ are rare in areas where the seastar is now abundant. The presence in the surface sediments of the shells of large adults indicates that this has not always been the case (Lockhart 1995). The predominance of juvenile molluscs, and particularly bivalves, in the diet of the seastar (Lockhart 1995, Morrice 1995) suggests that seastar predation on juveniles may be preventing the subsequent establishment and potential recovery of adult populations in the estuary. Over the period from December 1997 to January 1998, a massive settlement of the commercial bivalve Fulvia tenuicostata occurred in Ralphs Bay in the Derwent Estuary where seastars are abundant. We recorded juveniles at $530 \mathrm{~m}^{-2}$ in late January 1998. Although F. tenuicostata is common in sheltered soft sediments in areas outside the estuary where it is part of a small commercial fishery, it is rare in the sediments where seastars are abundant, despite the presence of numerous shell remains. Adult populations of F. tenuicostata were decimated by the seastar in experiments conducted outside the seastar's current range (Ross et al. in press). The mass settlement of $F$. tenuicostata provided an opportunity to test the hypothesis that seastar predation on juveniles can prevent the establishment and potential recovery of adult populations in the estuary. In this paper, we undertake a feeding survey comparing the abundance of prey taxa in the sediments and in seastar stomachs before, during and after the settlement event. We also carry out a manipulative experiment to assess the impact of Asterias on the survivorship of juvenile $F$. tenuicostata and the abundances of other species. Overall, the combined results of this study and those from related work (Ross 2001) provide the first quantitative estimates of the direct impact of the seastar on native assemblages and wild fisheries (Ross et al. in press).

\section{MATERIALS AND METHODS}

Background. The study was undertaken at Huxleys Beach $\left(42^{\circ} 58^{\prime} \mathrm{S}, 147^{\circ} 27^{\prime} \mathrm{E}\right)$ in Ralphs Bay, a large shallow embayment on the eastern side of the Derwent Estuary, southeast Tasmania, Australia, at a depth of 4 to $5 \mathrm{~m}$. The sediment at this site is composed predominantly of very fine to medium sands (Ross 2001). The habitat type at the study site is common in other areas of the Derwent Estuary and adjoining bays and estuaries. The habitat range of both species overlaps: Asterias occurs on sheltered silt to sand and on rocky reefs at 0 to $35 \mathrm{~m}$ depth, while Fulvia occurs on sheltered silt to sand at 0 to $30 \mathrm{~m}$ depth (Edgar 1997). The average density of Asterias amurensis recorded at this site prior to this study (1995 to 1996) was $0.53 \mathrm{~m}^{-2}( \pm 0.12)$ (Grannum et al. 1996, Ross 2001). In contrast, the bivalve Fulvia tenuicostata was absent in infaunal surveys at the site during the same period, despite the presence of numerous shells in the sediment. The vast majority of F. tenuicostata present at the site during this study were newly settled juveniles of small size (1 to $13 \mathrm{~mm}$ shell length; see Fig. 3a).

Manipulative experiment. Experimental design: The effects of seastar predation on the survival of juveniles of the commercial bivalve Fulvia tenuicostata and the abundance of other prey taxa was examined in a caging experiment conducted over a $10 \mathrm{wk}$ period between January and April 1998. Cages consisted of a rigid $(1 \times 1 \mathrm{~m}$ base $\times 0.7 \mathrm{~m}$ high) steel frame with protruding legs $(0.5 \mathrm{~m}$ long). The cage top and sides were 
covered in stiff plastic mesh $(6 \mathrm{~mm})$ and the cage legs were driven into the sediment so that 100 to $150 \mathrm{~mm}$ of the cage sides was buried to prevent passage of large predators or prey by burrowing. The treatments included: $\left(\mathrm{O}_{\text {initial }}\right)$ open unmanipulated plot subject to background predation (sampled at $0 \mathrm{wk}) ;\left(\mathrm{O}_{\text {final }}\right)$ open unmanipulated plot subject to background predation (sampled at $10 \mathrm{wk})_{;}(-\mathrm{S})$ caged exclusion, no seastars present; and $(+\mathrm{S})$ caged inclusion with a single seastar added (thus at a density of $1 \mathrm{~m}^{-2}$ ). Note that the $\mathrm{O}_{\text {initial }}$ and $\mathrm{O}_{\text {final }}$ treatments use separate plots.

The spatial scale of patchiness of infauna indicated in a pilot study suggested that a randomised complete block design was the most efficient option to test for treatment effects given the limited number of replicates possible due to logistical constraints in diving. In the pilot study, plots 3 to $5 \mathrm{~m}$ apart were similar in composition while plots separated by 30 to $60 \mathrm{~m}$ were usually dissimilar. Thus, the 4 treatments were applied randomly to separate experimental units ( $5 \mathrm{~m}$ apart) in each of 3 blocks ( $\sim 30 \mathrm{~m}$ apart). By accounting for the variation between blocks, we hoped to obtain a smaller experimental error and improve the power to detect treatment effects (see Newman et al. 1997).

Sampling of invertebrates: Two different sampling techniques were employed. First, treatment plots were sampled with cores (150 mm diameter, $100 \mathrm{~mm}$ deep) to estimate the abundance of all infaunal and epifaunal organisms (>1 mm). Because it was not anticipated that core samples would provide precise estimates of the abundance of larger and/or rare species that may be important prey of the seastar, the entire contents of the plots were subsequently sampled to a depth of $0.1 \mathrm{~m}$ using a diver-operated, air-driven suction device. To do this, an open square frame $(1 \times 1 \mathrm{~m})$ was inserted into the sediment to isolate the plot and all contents vacuumed into a $1 \mathrm{~mm}$ mesh bag. Sampling in both cores and air-lift samples was to a depth of $0.1 \mathrm{~m}$ because the vast majority of macroinvertebrate infauna was found in this depth range in a pilot study. (D.J.R. unpubl.)

At the commencement of the experiment, 3 replicate cores were taken at random positions in each of the $\left(\mathrm{O}_{\text {initial }}\right)$ unmanipulated treatment plots. After coring, the entire contents of the plots were sampled using the suction device as described above. Remaining treatments were then monitored weekly to check the condition of the enclosed predators and to remove fouling organisms from the cages. Ten wk after commencement of the experiment, cages and predators were removed, and 3 cores were taken from the $\left(\mathrm{O}_{\text {final }}\right)$ unmanipulated, caged inclusion and exclusion plots as described above. No samples were taken within $\sim 100 \mathrm{~mm}$ of the cage perimeter to avoid possible edge effects of the cages. After coring, the entire contents of the $\left(\mathrm{O}_{\text {final }}\right)$ unmanipulated, caged inclusion and exclusion plots were sampled using the suction device as described above.

Samples were sieved (1.0 mm mesh) prior to fixing in 5 to $10 \%$ buffered formalin with Rose Bengal stain, and then rinsed in freshwater before storing in $100 \%$ ethanol. For core samples, all infaunal and epifaunal organisms $(>1 \mathrm{~mm}$ ) were sorted and identified to the lowest possible taxon. In all core samples, the shell length of the commercial bivalve Fulvia tenuicostata was measured to the nearest $\mathrm{mm}$. Suction samples were sieved again $(2.0 \mathrm{~mm}$ mesh) and all bivalves, crabs and the echinoid Echinocardium cordatum sorted and identified to species.

Statistical analysis: The responses of numerically abundant taxa to experimental treatments were analysed using univariate statistics. Responses were determined using species abundance data from suction samples with the exception of polychaetes, gastropods and amphipods, which were counted in cores. For the analysis of cores, the arithmetic mean of the 3 replicate cores taken from each plot was used. A randomised complete block ANOVA, with 'treatment' (4 levels $=\mathrm{O}_{\text {initial }}, \mathrm{O}_{\text {final }}+\mathrm{S}$ and $-\mathrm{S}$ ) as a fixed factor, and 'block' as a random factor, was used to test for the effect of seastars and cages (see below). In the analysis, we make no assumptions about additivity (Newman 1997) and note that the test for the 'treatment' effect is statistically valid whether there is an interaction between treatment and block or not. However, interpreting the significance of the 'treatment' effect requires no, or a relatively small, treatment by block interaction. To assess treatment by block interactions, plots of dependent variables versus block were examined. In cases where an interaction was clearly evident by visual inspection, the analysis was not conducted. In regard to the assumption of constant variance among blocks, variances are unlikely to be greatly different between blocks because the treatments were applied randomly to different experimental units within each block. Data were checked for normality and homoscedasticity, and transformed as necessary depending on the relationship between SDs and means of treatment groups (ignoring the blocking effect) (Draper \& Smith 1981). The statistical package SAS (Statistical Analysis System) was used for analyses.

Three planned comparisons (1 orthogonal and 2 non-orthogonal) were carried out following the initial analyses to test for seastar and caging effects. For planned comparisons, we adjusted the significance level using the conservative method of Todd \& Keough (1994), i.e. $\alpha$ was reduced to $\alpha /(1+$ the number of non-orthogonal contrasts). With 2 non-orthogonal and 1 orthogonal comparison, the significance level was adjusted to 0.016 . Following Todd \& Keough 
(1994), the exact probabilities are presented in recognition of the lack of consensus about the appropriate adjustment of the significance level. The contrasts were: (1) $\mathrm{O}_{\text {initial }}$ vs $\mathrm{O}_{\text {finali }}$ this assesses the change in invertebrate abundance over the experimental period in open unmanipulated plots. In particular, this will measure the natural change in abundance of Fulvia tenuicostata juveniles (and other taxa) in the presence of seastars at their background density over the course of the experiment. While this treatment is not critical to the assessment of seastar effects, it provides useful biological information. (2) $-\mathrm{S}$ vs $+\mathrm{S}_{\text {; }}$ this assesses the effect of seastars on invertebrate abundances, contrasting treatments with and without seastars. (3) $\mathrm{O}_{\text {final }} \mathrm{vs}+\mathrm{S}$; this examines caging effects not associated with the removal of seastars, such as the exclusion of other predators and cage-induced changes to predator behaviour. In interpreting this comparison, it is recognised that the seastar density in the cage was higher $\left(1 \mathrm{~m}^{-2}\right)$ than the mean background density (ca. 0.09 to $0.4 \mathrm{~m}^{-2}$ over the course of the study). We note however that the distribution of unmanipulated seastars became highly aggregated when they were feeding on juvenile Fulvia tenuicostata and densities at $1 \mathrm{~m}^{-2}$ were recorded.
These aggregations were found during the period that we conducted our experiment.

Dietary survey. To identify prey species that were consumed disproportionately by Asterias amurensis relative to their occurrence in the environment and, in particular, any changes in the diet associated with the settlement of Fulvia tenuicostata, we compared macroinvertebrate abundance in the sediment and in seastar stomachs before, during and after the settlement event.

Sediments: Invertebrate abundances were measured in 1 suction sample (as described above) and in 3 infaunal cores (as described above, $1 \mathrm{~m}$ apart) at each of 3 random positions ( $30 \mathrm{~m}$ apart). These samples were taken in November 1997, January 1998 (at the start of the manipulative experiment), April 1998 (at the conclusion of the manipulative experiment) and in November 1998. The samples obtained in January and April 1998 were those from the open plots in the manipulative experiment.

Stomach contents: Dietary information was assessed by examining the stomach contents of the first 50 seastars encountered on 3 randomly placed $50 \times 2$ m strip transects at the study site. Samples of seastars were taken in November 1997, February 1998 (4 wk into the

Table 1. Analysis of effects of seastar predation and caging effects on the abundances of numerically abundant taxa. The table shows results for each taxon of the overall ANOVA comparing among treatments of $\mathrm{O}_{\text {initial }}$ (open unmanipulated plot, subject to background predation sampled at $0 \mathrm{wk}$ ); $\mathrm{O}_{\text {final }}$ (open unmanipulated plot, subject to background predation sampled at $10 \mathrm{wk}$ ); $-\mathrm{S}$ (caged exclusion, no seastars present); and $+\mathrm{S}$ (caged inclusion, a single seastar). Results of 3 planned comparisons are also given. Significant p-values are shown in bold face: $\mathrm{p}$-values $<0.05$ are significant for the 'main analysis' and $\mathrm{p}$-values $<0.016$ are significant for the planned comparisons. ${ }^{*}$ Species was absent in at least 1 of the groups being compared

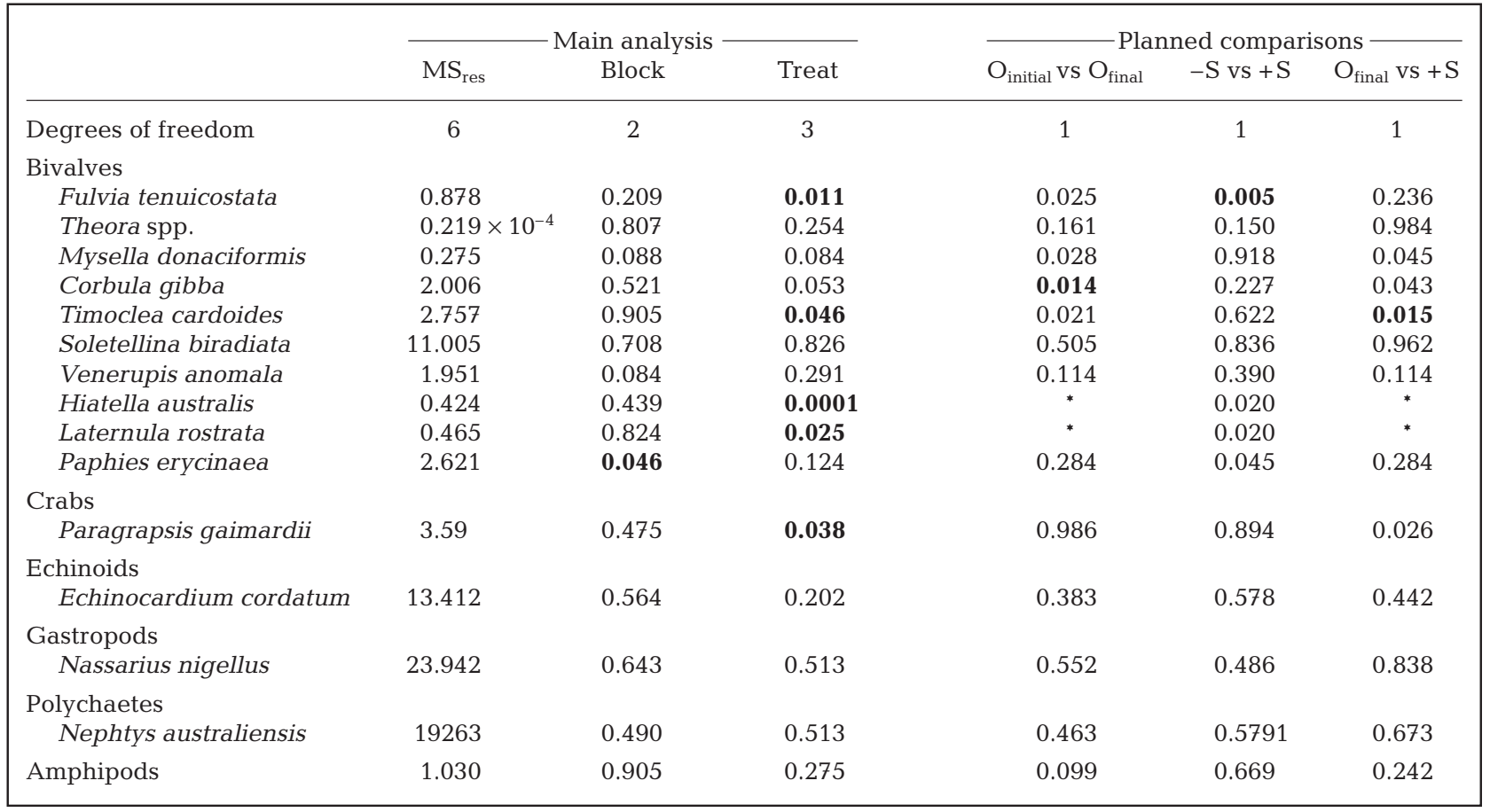


manipulative experiment), April 1998 (at the conclusion of the manipulative experiment) and in November 1998. All seastars were placed immediately in sealed plastic bags upon collection to prevent the loss of regurgitated stomach contents. Because the seastar exhibits both extra and intraoral modes of feeding, care was taken in collecting them so that prey items consumed extraorally at the time of collection were also collected into the plastic bags. Seastars were frozen within a few $\mathrm{h}$ of collection and thawed prior to examination.

Dietary analysis: Because of differences in digestion rates and the effect of freezing, the ability to identify and count individuals in stomach samples varied between taxa. In contrast to bivalves and gastropods, polychaetes, crustaceans and other soft bodied macroinvertebrates were more difficult to identify and count in stomach samples. However, in most cases the identity and number of individuals present was clear, as evidenced by the presence of a head capsule, limb or complete body. Nonetheless, when digestion was nearly complete (polychaetes) or when there were several small pieces of crustacean exoskeleton present, the exact number of individuals was uncertain. Accordingly, we used 2 methods to calculate the proportion of each prey taxon in the diet of the seastar: (1) proportion of the total numerical abundance where the presence of animal remains enabled counting multiple individuals with certainty; and (2) proportion of the total stomach contents based on a binary classification, i.e. all prey taxa were scored as either present (1) or absent (0). We compared patterns of prey composition and prey preferences (see below) calculated using both methods.

To identify prey species that were consumed disproportionately by Asterias amurensis relative to their occurrence in the environment, Vanderploeg \& Scavia's (1979) relativised electivity index $(E)$ was calculated. The index is defined as:

$$
E_{i}=\left(W_{i}-\frac{1}{\mathrm{n}}\right) /\left(W_{i}+\frac{1}{\mathrm{n}}\right)
$$

where

$$
W_{i}=\frac{r_{i} / p_{i}}{\sum_{i}\left(r_{i} / p_{i}\right)}
$$

and $\mathrm{n}=$ the number of kinds of food items, $r_{i}=$ the proportion of the $i$ th food in the diet, and $p_{i}=$ the proportion of the $i$ th food in the environment. The index for each taxon has a possible range from -1 to +1 . A value of 0 denotes that the taxon is taken in proportion to its abundance; 1 signifies that the taxon is preferred and exclusive in the diet; and -1 indicates that the species is avoided. Taxa only found in stomach contents but not in samples from the environment were given a value of +1 and not considered further in calculations of electivity. Given that the electivity coefficient confounds predator choice and ecological availability of prey (as it is based on numerical availability and not functional availability), preference does not necessarily imply active choice but may also indicate that a prey is ecologically more available to the predator. However, the primary question in this study is about the predator's impact on prey, rather than the behavioural mechanisms underlying it.

\section{RESULTS}

\section{Manipulative experiment}

\section{Relative abundance of macro-invertebrates}

The major groups found in the core samples in decreasing order of numerical abundance were polychaetes, bivalves, amphipods and gastropods. The dominant taxa in each group in decreasing order of numerical abundance were the polychaete Nephtys australiensis, the bivalves Theora spp., Fulvia tenuicostata and Mysella donaciformis, and the gastropod Nassarius nigellus. Due to very low abundances and the taxonomic difficulties associated with species level identification, amphipods were not resolved below the level of order. The major species found in suction samples in decreasing order of numerical abundance were the bivalves $F$. tenuicostata, Theora spp. and Mysella donaciformis; the native crab Paragrapsis gaimardii; the bivalve Corbula gibba; the echinoid Echinocardium cordatum; and the bivalves Hiatella australis, Timoclea cardoides, Venerupis anomala, Soletellina biradiata, Laternula rostrata and Paphies erycinaea.

Changes in the abundance of macroinvertebrates in unmanipulated plots

Abundances of Fulvia tenuicostata and Mysella donaciformis decreased over the experimental period, however, the change was not significant at the adjusted $\alpha$ level $\left(\alpha_{\text {adjusted }}=0.016\right)\left(\mathrm{O}_{\text {initial }}\right.$ vs $\mathrm{O}_{\text {finali }}$ Table 1, Fig. 1$)$. In contrast, densities of Corbula gibba, Timoclea cardoides, Theora spp., Soletellina biradiata, Venerupis anomala, Echinocardium cordatum, Nephtys australiensis and amphipods increased over the experimental period, however this change was only significant at the adjusted $\alpha$ level for C. gibba (Table 1, Figs. 1 \& 2). Laternula rostrata, Hiatella australis, Paragrapsis gaimardii and Nassarius nigellus were absent or in very low densities in unmanipulated plots at the start and end of the experiment (Table 1, Figs. 1 \& 2). 
Fulvia tenuicostata
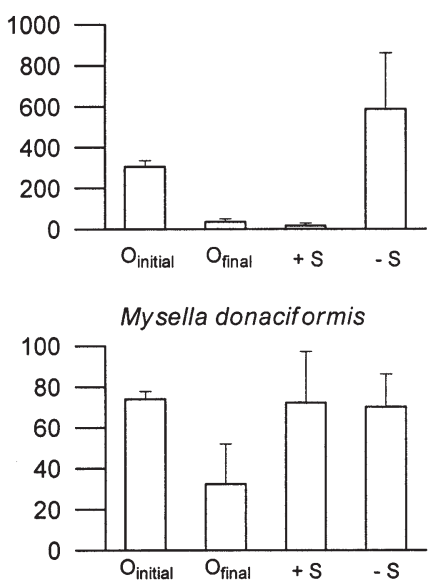

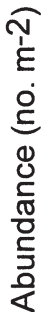





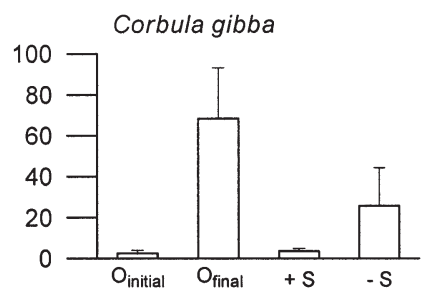

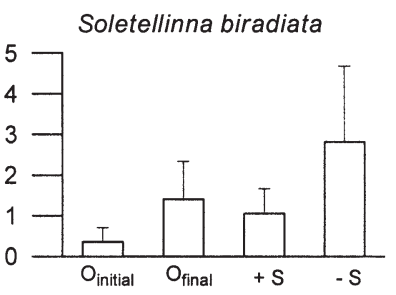
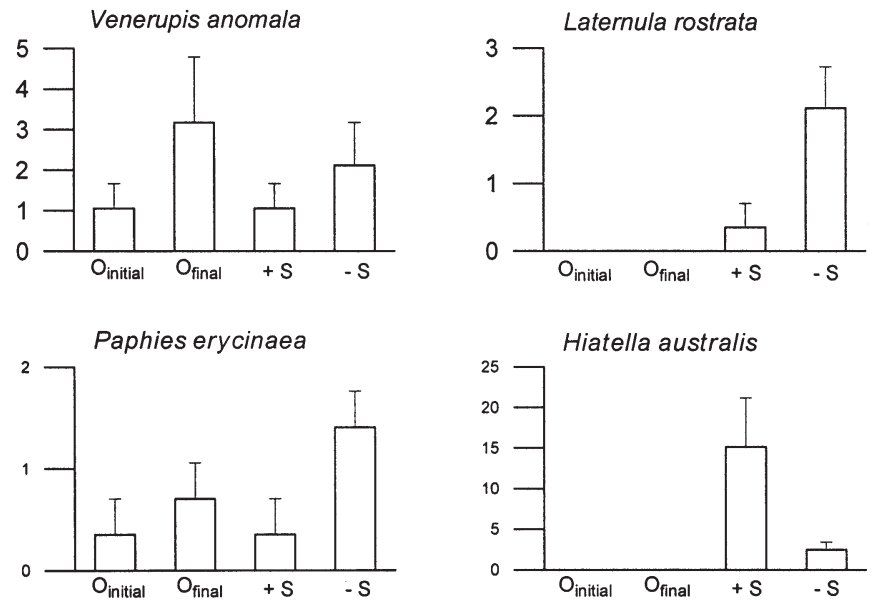

Fig. 1. Densities of the most abundant bivalve species. Densities are means $\mathrm{m}^{-2}(+\mathrm{SE})$ taken from suction samples to a depth of $100 \mathrm{~mm}(\mathrm{n}=$ 3 plots). $\mathrm{O}_{\text {initial }}=$ open unmanipulated plot, subject to normal predation (sampled at $0 \mathrm{wk}) ; \mathrm{O}_{\text {final }}=$ open unmanipulated plot, subject to normal predation (sampled at $10 \mathrm{wk}$ ) $;-\mathrm{S}=$ caged exclusion, no seastars present; and $+\mathrm{S}=$ caged inclusion, a single seastar added (thus $1 \mathrm{~m}^{-2}$ )

in plots where seastars were excluded (Fig. 3), demonstrating that survival into larger sizes was truncated by predation. At the end of the experiment, densities of $F$. tenuicostata in the cage inclusion and unmanipulated treatments were $\sim 17$ and $\sim 35 \mathrm{~m}^{-2}$, respectively, while in the treatment protected from seastar predation, densities were $\sim 580 \mathrm{~m}^{-2}$.

Abundances of Paphies erycinaea and Laternula rostrata were also greater when seastars were excluded, consistent with a seastar effect; however, the differences were not significant at the adjusted $\alpha$ level $\left(\alpha_{\text {adjusted }}=\right.$ 0.016) (-S vs $+S_{i}$ Table 1, Fig. 1). In contrast, the abundance of Hiatella australis was significantly higher in the presence of seastars (-S

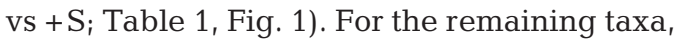
differences between treatments with and without seastars were not significant (Table 1, Figs. $1 \& 2$ ).

\section{Caging effects}

In the presence of seastars, densities of the crab Paragrapsis gaimardii, bivalve Mysella donaciformis and gastropod Nassarius nigellus were greater in caged compared with uncaged treatments, however these differences were not significant at the adjusted $\alpha$ level $\left(\alpha_{\text {adjusted }}=0.016\right)\left(\mathrm{O}_{\text {final }} \mathrm{vs}+\mathrm{S}\right.$; Table 1, Figs. $1 \& 2$ ). The bivalves Laternula rostrata and Hiatella australis occurred only in the presence of cages (Fig. 1). In contrast, densities of Timoclea cardoides, Venerupis anomala and Corbula gibba were reduced in caged compared with uncaged treatments, however this difference was only significant at the adjusted $\alpha$ level $\left(\alpha_{\text {adjusted }}=0.016\right)$ for $T$. cardoides (Table 1, Fig. 1). For the remaining taxa, differences were not significant between the caged and uncaged treatments with seastars present (Table 1, Figs. 1 \& 2).

\section{Dietary survey}

\section{Sediments}

\section{Effects of seastars}

There was a significant reduction in the abundance of Fulvia tenuicostata in the presence of seastars (-S vs $+\mathrm{S}$; Table 1, Fig. 1). The mean size of F. tenuicostata increased from $3.79( \pm$ SE 0.25$)$ to $18.88( \pm$ SE 0.59$) \mathrm{mm}$
The major groups of infauna were polychaetes, bivalves, crustaceans and gastropods, which represented $60,23,11$ and $3 \%$, respectively, of the total numerical abundance pooled across sampling times. However, the relative abundance and composition of each group varied considerably over the sampling 

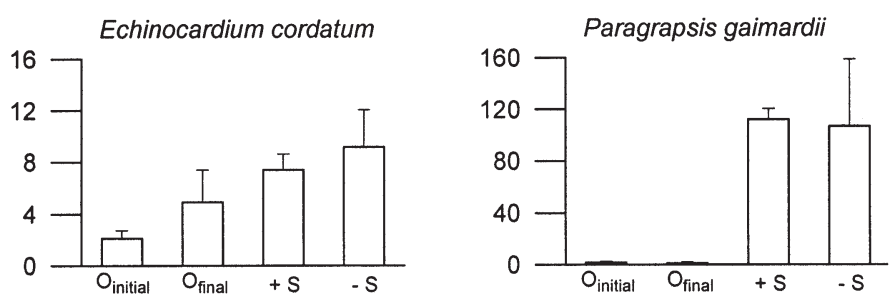

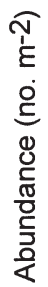
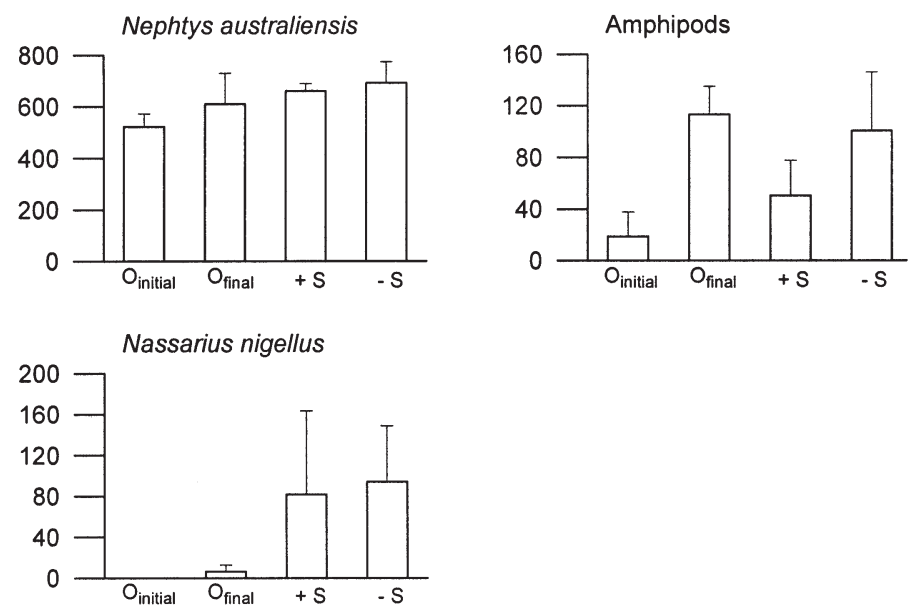

Fig. 2. Densities of the most abundant polychaete, crustacean, gastropod and echinoid taxa in each treatment. Densities of the echinoid Echinocardium cordatum and the crustacean Paragrapsis gaimardii are means $\mathrm{m}^{-2}(+\mathrm{SE})$ taken from suction samples to a depth of $100 \mathrm{~mm}$ ( $\mathrm{n}=3$ plots). Densities of the polychaete Nephtys australiensis, gastropod Nassarius nigellus and amphipods are means $\mathrm{m}^{-2}$ $(+\mathrm{SE})$ scaled from counts in cores $(\mathrm{n}=3$ cores pooled, each $150 \mathrm{~mm}$ diameter, $100 \mathrm{~mm}$ deep) in each plot ( $\mathrm{n}=3$ plots). Abbreviations are as in Fig. 1 rence of total bivalves, polychaetes and crustaceans in the diet of seastars tracked changes in relative abundance of these groups in the environment (Fig. 4). Polychaetes and crustaceans were more common in the diet in the first and last surveys, when their relative abundances in the sediments were greatest (Fig. 4). In contrast, bivalves were clearly the most common prey items in the middle 2 surveys (February and April 1998) when their relative abundance in sediments was greatest (Fig. 4). Fulvia tenuicostata was clearly the major prey item at these times, representing 76 (69) and 52 (39)\% of the seastar's diet respectively (Fig. 5). Following the decline in abundance of F. tenuicostata, the absolute and relative abundances of the bivalves Corbula gibba and Venerupis anomala, and the gastropod Nassarius nigellus, increased in the sediments. These species were then consumed by the seastar until their densities in the environment were negligible (Fig. 5). In November 1997 and 1998, polychaetes, crustaceans, Echinocardium cordatum and the bivalves Theora spp. and Timoclea cardoides were the major prey items of the seastar (Figs. 4 \& 5).

Dietary analysis

Prey preferences calculated from numerical and binary data were similar for the major taxa period (Figs. 4 \& 5), e.g. bivalves comprised 5 and $9 \%$ of the total abundance in November 1997 and November 1998, respectively, compared with 44 and $28 \%$ in January and April 1998, respectively. This pattern reflected settlement of some species, particularly Fulvia tenuicostata, early in the year and subsequent mortality of nearly all the major bivalve species between November 1997 and November 1998 (Fig. 5).

\section{Stomach contents}

Patterns of prey consumption calculated from numerical and binary data were similar for all major groups and taxa (Figs. 4 \& 5). The major groups found in seastar stomachs were bivalves, crustaceans, gastropods, polychaetes and the urchin Echinocardium cordatum representing 62 (52), 19 (25), 8 (9), 6 (8) and $4(6) \%$, respectively, of the total stomach contents of all seastars pooled across sampling times (binary data shown in parentheses). Temporal shifts in the occur- (a)
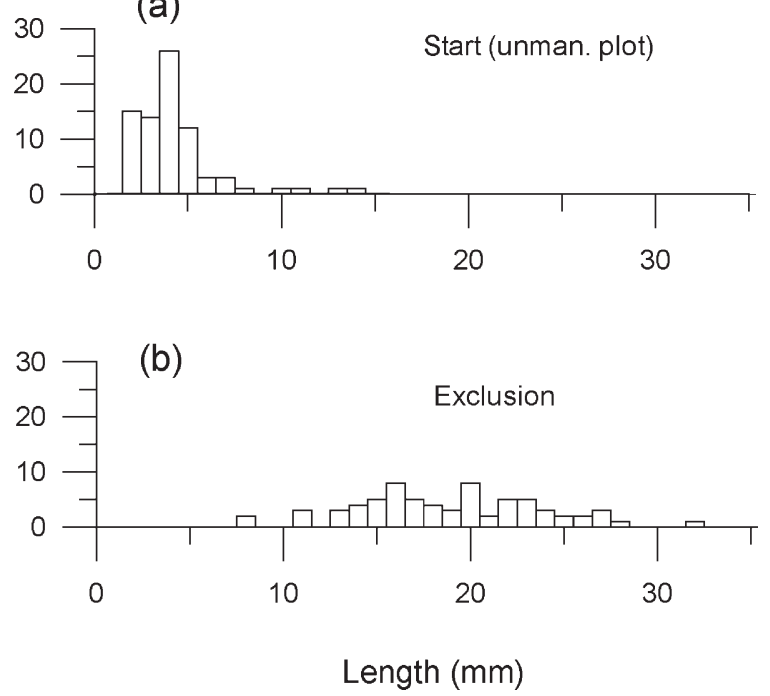

Fig. 3. Length frequency histograms of the commercial bivalve Fulvia tenuicostata from (a) open unmanipulated plots at the start of the experiment and (b) cages excluding seastars sampled at the end of the experiment 
Bivalves

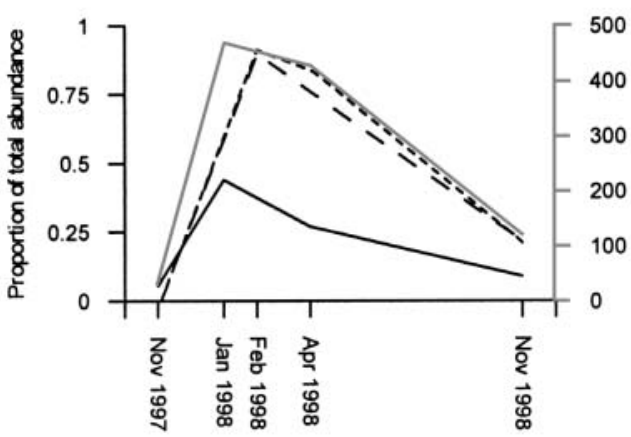

Polychaetes

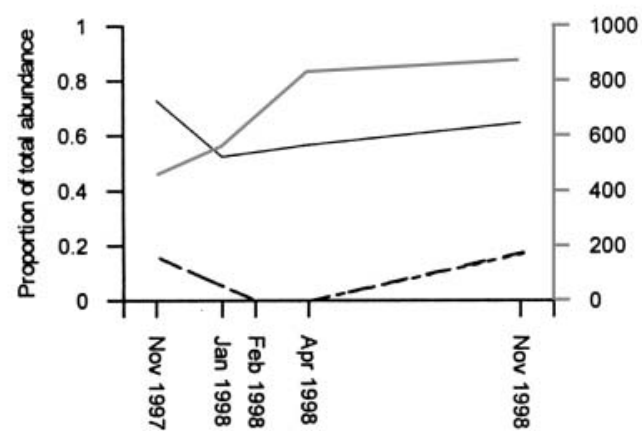

Crustaceans

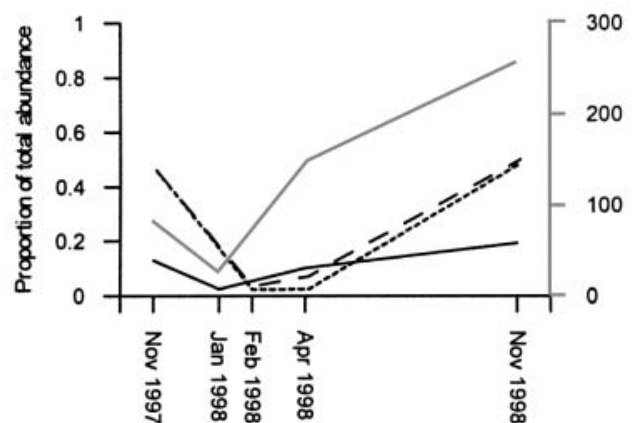

Echinoids

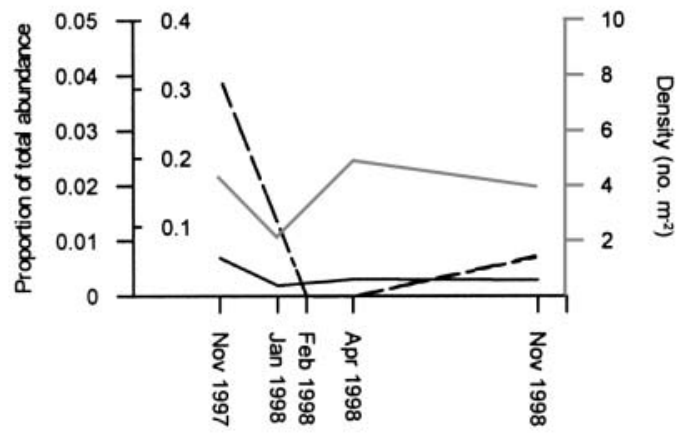

Gastropods

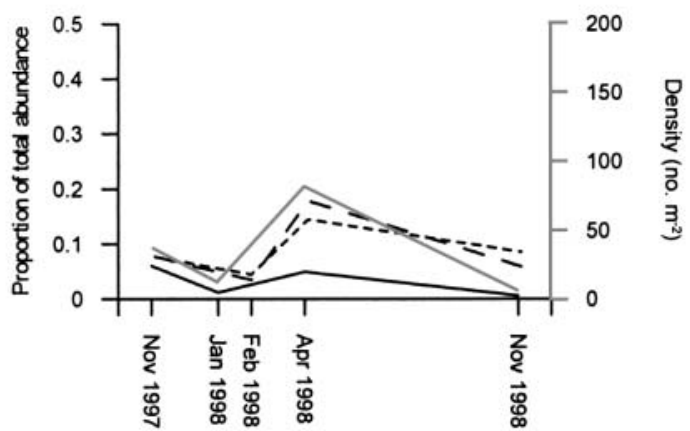

LEGEND

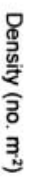

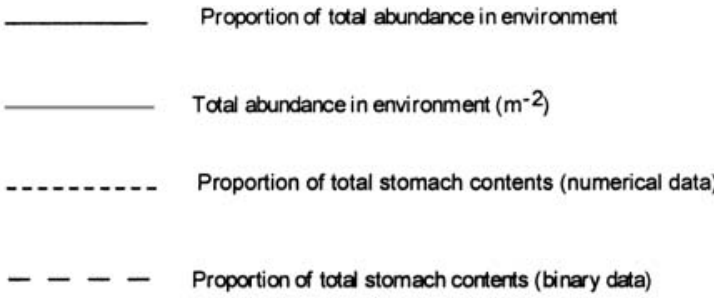

Fig. 4. Proportion of the total abundance of the major groups of prey in seastar stomachs and in sediments, and the absolute abundance in the sediments. The $y$-axis on the left depicts proportions in the diet and sediments. (Note: When 2 scales are marked, the left-hand scale is the proportion of total abundance in the sediments.) The $y$-axis on the right represents the absolute abundance in the sediments $\left(\mathrm{m}^{-2}\right)$. Densities are determined from $1 \mathrm{~m}^{2}$ suction samples, with the exception of polychaetes, crustaceans and gastropods, which were extracted from core samples

(Table 2). It is clear that the main prey items in summer (January to April 1998), i.e. the bivalves Fulvia tenuicostata, Corbula gibba, Venerupis anomala and the gastropod Nassarius nigellus, were consumed in much greater proportion to their relative abundance in the environment (Table 2). However, in late spring (November) when the abundances of these species in sediments were low, the echinoid Echinocardium corda- tum and the bivalve Timoclea cardoides were preferred. Whilst polychaetes were major prey items in late spring, they were not preferred. In contrast, crustaceans were consumed in greater proportion to their abundance in the environment in November 1997 and consumed in (approximately) direct proportion to their occurrence in the environment in November 1998. Invertebrates that were relatively common in the sedi- 



\section{LEGEND}

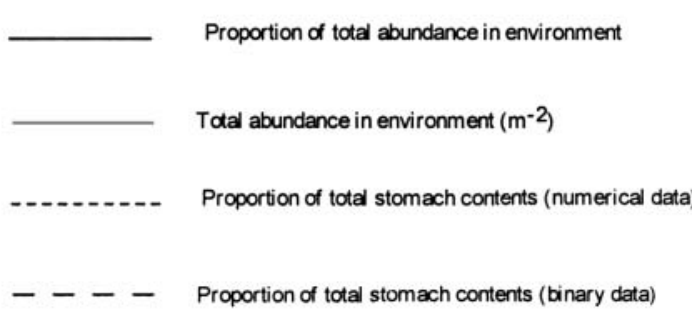

Fig. 5. Proportion of the total abundance of the major bivalve species and the gastropod Nassarius nigellus in seastar stomachs and in sediments, and the absolute abundance in the sediments. The $y$-axis on the left depicts the proportion in the diet and sediments. (Note: When 2 scales are marked, the left-hand scale is the proportion in the sediments.) The $y$-axis on the right represents the mean absolute abundance in sediments $\left(\mathrm{m}^{-2}\right)$. Densities are determined from $1 \mathrm{~m}^{2}$ suction samples, with the exception of Nassarius nigellus, which was extracted from core samples 
Table 2. Frequency (\%) and electivity coefficients for macroinvertebrates in the sediments and stomach contents of 46,20 and 49 Asterias amurensis collected from Ralphs Bay during November 1997, April 1998 (Week 8 of experiment) and November 1998, respectively. Frequency (\%) of macroinvertebrates in the diet is calculated using the total stomach contents based on numerical and binary data. Results based on binary data are in parentheses (note in November 1997 the results based on numerical and binary data are identical). Taxa showing positive values of electivity are presented in bold. na: not available

\begin{tabular}{|c|c|c|c|c|c|c|c|c|c|}
\hline \multirow{3}{*}{ Taxon } & \multirow{2}{*}{\multicolumn{2}{|c|}{$\begin{array}{l}\text { Nov } 1997 \\
\text { Frequency (\%) }\end{array}$}} & \multirow{3}{*}{$\begin{array}{l}\text { Electivity } \\
\text { index }\end{array}$} & \multirow{2}{*}{\multicolumn{2}{|c|}{$\begin{array}{l}\text { Apr } 1998 \\
\text { Frequency (\%) }\end{array}$}} & \multirow{3}{*}{$\begin{array}{l}\text { Electivity } \\
\text { index }\end{array}$} & \multirow{2}{*}{\multicolumn{2}{|c|}{$\begin{array}{l}- \text { Nov } 1998 \\
\text { Frequency }(\%)\end{array}$}} & \multirow{3}{*}{$\begin{array}{l}\text { Electivity } \\
\text { index }\end{array}$} \\
\hline & & & & & & & & & \\
\hline & $\begin{array}{l}\text { Sub- } \\
\text { stratum }\end{array}$ & $\begin{array}{l}\text { Stomach } \\
\text { contents }\end{array}$ & & $\begin{array}{c}\text { Sub- } \\
\text { stratum }\end{array}$ & $\begin{array}{l}\text { Stomach } \\
\text { contents }\end{array}$ & & $\begin{array}{c}\text { Sub- } \\
\text { stratum }\end{array}$ & $\begin{array}{l}\text { Stomach } \\
\text { contents }\end{array}$ & \\
\hline \multicolumn{10}{|l|}{ Bivalves } \\
\hline Fulvia tenuicostata & 0.1 & 0 & - & 2.8 & $51.8(39.3)$ & $0.69(0.58)$ & 0 & 2.9 & +1 \\
\hline Theora spp. & 3.4 & 0 & -1 & 21.5 & 0 & -1 & 5.9 & $8.6(8.8)$ & $-0.43(-0.43)$ \\
\hline Mysella donaciformis & 0.7 & 0 & - & 2.5 & 0 & -1 & 2.6 & 0 & -1 \\
\hline Corbula gibba & 0.1 & - & - & 5.3 & $24.1(25.0)$ & $0.14(0.10)$ & 0.1 & 0 & - \\
\hline Timoclea cardoides & 0.7 & 0 & - & 0.5 & 0 & - & 0.4 & $8.6(8.8)$ & $0.73(0.73)$ \\
\hline Laternula rostrata & - & - & - & - & $2.4(3.6)$ & +1 & - & - & - \\
\hline Venerupis anomala & - & - & - & 0.2 & $2.4(3.6)$ & $0.48(0.58)$ & - & - & - \\
\hline Electroma georgina & - & - & - & na & $2.4(3.6)$ & - & - & - & - \\
\hline \multicolumn{10}{|l|}{ Gastropods } \\
\hline Nassarius nigellus & - & - & - & 0.5 & $14.5(17.9)$ & $0.80(0.82)$ & 0 & 5.7 & +1 \\
\hline Fusinus novaehollandiae & e 0 & 7.7 & +1 & - & - & - & - & - & - \\
\hline Retusa pelyx & 3.0 & 0 & -1 & 0.5 & 0 & - & - & - & - \\
\hline Philine angasi & 1.0 & 0 & -1 & - & - & - & 2.3 & 0 & -1 \\
\hline Gastro sp1 & 2.0 & 0 & -1 & - & - & - & - & - & - \\
\hline Gastro sp2 & 1.0 & 0 & -1 & - & - & - & - & - & - \\
\hline Gastro sp3 & - & - & - & - & - & - & 0 & 2.9 & +1 \\
\hline \multicolumn{10}{|l|}{ Echinoids } \\
\hline Echinocardium cordatum & n 0.7 & 30.8 & 0.87 & 0.5 & 0 & - & 0.3 & $5.7(5.9)$ & $0.69(0.69)$ \\
\hline Crustaceans & 13.0 & 46.2 & 0.05 & 9.7 & $2.4(7.1)$ & $-0.86(-0.67)$ & 19.1 & $48.6(50.0)$ & $-0.17(-0.17)$ \\
\hline Polychaetes & 73.2 & 15.4 & -0.88 & 55.0 & 0 & -1 & 64.7 & $17.1(17.6)$ & $-0.86(-0.86)$ \\
\hline Sipunculids & - & - & - & - & - & - & 1.9 & 0 & -1 \\
\hline Ascidians & 1.0 & 0 & -1 & - & - & - & - & - & - \\
\hline Flatworms & - & - & - & - & - & - & 1.9 & 0 & -1 \\
\hline
\end{tabular}

ment, but clearly not preferred, were: the bivalves Mysella donaciformis and Theora spp.; the gastropods Retusa pelyx and Philine angasi, plus 2 unidentified gastropod species; ascidians; flatworms; and sipunculids. In contrast, the bivalve Laternula rostrata, gastropod Fusinus novaehollandiae and an unidentified gastropod were found in the diet but not in the sediments.

\section{DISCUSSION}

\section{Direct effects of seastar predation on the survivorship of Fulvia juveniles}

Numerous observational studies suggest that asteroids may play a major role in structuring bivalve populations in soft-sediment habitats (e.g. Christensen 1970, Anger et al. 1977, Fukuyama \& Oliver 1985, Nojima 1988). However, in contrast to hard bottom benthos (e.g. Dayton 1971, Paine 1974, Robles et al. 1995), far fewer studies have demonstrated experimentally the influence of asteroid predation on bivalve populations in soft sediments (but see e.g. Thrush 1986, Peterson \& Black 1993). Using a combination of experimental and observational approaches, the present study demonstrates the impact of Asterias amurensis on the survivorship of recently settled juveniles of the commercial bivalve Fulvia tenuicostata. After $10 \mathrm{wk}$, the mean density of $F$. tenuicostata was reduced from ca. $300 \mathrm{~m}^{-2}$ at the beginning of the experiment to ca. $35 \mathrm{~m}^{-2}$ in the presence of seastars at natural densities and $17 \mathrm{~m}^{-2}$ in cage inclusions where seastar density was $1 \mathrm{~m}^{-2}$. In marked contrast, in the treatment from which $A$. amurensis was excluded, the mean density of $F$. tenuicostata was ca. $580 \mathrm{~m}^{-2}$ at the end of the experiment. The mean size of $F$. tenuicostata increased dramatically in seastar exclusions over the experimental period. The increase in density over the experimental period most likely reflects the growth of juveniles into size classes that are retained on the $2 \mathrm{~mm}$ mesh sieve which was used to assess abundances. Densities of ca. $530 \mathrm{~m}^{-2}$ were recorded at the start of the experiment when juveniles retained on a $1 \mathrm{~mm}$ mesh sieve were counted. Given our observations of seastar feeding, we 
interpret the large reduction in bivalves in cages containing $A$. amurensis relative to the cage exclusions to indicate seastar predation. The seastar responded similarly to the settlement of $F$. tenuicostata in the unmanipulated area, as evidenced by a pronounced shift in diet. This bivalve was the most common prey species of A. amurensis following its mass settlement, representing 50 to $80 \%$ of the seastar's dietary items in February and April 1998. These findings are consistent with observations in the native habitat of the seastar where it is a major predator of bivalves including cockles, oysters, scallops and other clams (Hatanaka \& Kosaka 1959, Kim 1969, Nojima et al. 1986).

The bivalves Laternula rostrata and Paphies erycinaea were the only other prey taxa for which the experimental results indicated an impact of the seastar on their abundance. This is consistent with previous observations of feeding, which identified $P$. erycinaea as a common prey item of the seastar (Lockhart 1995, Grannum et al. 1996). Although it was absent from unmanipulated plots at the start and end of the experiment, L. rostrata was recorded in seastar stomachs and was present in the treatment from which seastars were excluded. While the results are indicative of a seastar effect, the presence of $L$. rostrata at low levels in seastar inclusion treatments relative to open plots where it was absent suggests that it may also be subject to losses from other predators.

\section{Caging artefacts}

Caging artefacts may have compromised the ability to detect seastar effects for some taxa. While caging experiments have been important in elucidating the role of predators in structuring marine benthic communities (see Peterson 1979, Ólafsson et al. 1994, Thrush 1999), the potential for cage artefacts to confound true treatment effects is widely acknowledged (e.g. Virnstein 1978, Dayton \& Oliver 1980, Hulberg \& Oliver 1980, Hall et al. 1990, Ólafsson et al. 1994, Fernandes et al. 1999, Thrush 1999). At the end of the experiment, the abundance of the bivalves Corbula gibba, Timoclea cardoides, Theora spp. and Venerupis anomala were reduced in both caged treatments, irrespective of seastar density, compared with open plots. In contrast, the bivalves Laternula rostrata and Hiatella australis were detected only in caged treatments. Artefacts of caging may have contributed to the change in abundance of these species in cages.

In contrast to Fulvia tenuicostata, which settled prior to the experiment, all bivalves that were recorded in lower abundances in the caging treatments settled during the experiment. Thus, settlement may have been suppressed by changes in water flow and/or settlement behaviour around cages. Also, predation by the crab Paragrapsis gaimardii may have confounded the effect of manipulating seastars since densities of $P$. gaimardii, a known bivalve predator, were 60 to 110 times higher in all treatments with cages compared with open plots. F. tenuicostata settled prior to the experiment and may either have reached a size refuge from crab predation (Ross 2001) or have been too abundant for the crab to have much impact. In contrast, Corbula gibba, Timoclea cardoides, Theora spp. and Venerupis anomala were likely to be susceptible to crab predation as they settled during the experiment and were available to the aggregation of crabs in cages at a much smaller size. For the bivalves that had greater abundances in the caging treatments (Laternula rostrata and Hiatella australis), exclusion of other predators by the cages is a possible explanation.

It is important to note that potential effects of cage artefacts are unlikely to compromise the tests for direct effects of the seastar. This is because caging effects are unlikely to account for lower abundances of some bivalves in cages containing seastars compared with cage exclusions. Moreover, Fulvia tenuicostata, Laternula rostrata, Corbula gibba, Timoclea cardoides and Venerupis anomala were identified as preferred prey items of Asterias amurensis in the feeding survey (Table 2). Soletellina biradiata and Paphies erycinaea have been recorded as common prey items of $A$. amurensis in other studies in the estuary (Lockhart 1995, Morrice 1995, Grannum et al. 1996). It is concluded that the lower densities of bivalves in cage inclusions compared with identical cages without seastars are indicative of a seastar effect. Nonetheless, in interpreting this contrast we assume that the cage has not greatly affected the behaviour of the seastar. While caging of a single animal may preclude any intraspecific inhibitory or facilitative behaviour that may influence feeding rate in nature, it needs to be emphasised that seastar densities similar to and substantially higher than those in the cages are frequently encountered in the Derwent Estuary (Grannum et al. 1996, S. D. Ling pers. comm.) for periods much greater than the $10 \mathrm{wk}$ experimental period. Thus, we suggest it is reasonable to expect similar effects on native species should the seastar attain the densities used in these experiments. This was supported from feeding observations in the non-experimental area at this site where aggregations of seastars consumed virtually all the Fulvia tenuicostata, as anticipated from the experiments.

\section{Prey switching and food preferences}

That significant impacts on only Fulvia tenuicostata were detected in the short-term (10 wk) caging exper- 
iment does not preclude that seastars may have effects on other taxa in the longer term. In this study, seastars fed prominently on $F$. tenuicostata after its massive settlement, but shifted to feed on other species when the bivalve became rare. As the abundance of $F$. tenuicostata declined, other bivalves (Corbula gibba and Venerupis anomala) and the gastropod Nassarius nigellus were increasingly consumed by the seastar until their populations also declined to low levels by late spring (November 1998). This is consistent with previous studies in the estuary, in which Asterias amurensis was found to be highly selective of V. anomala (Lockhart \& Ritz 2001), Venerupis spp. and N. nigellus (Grannum et al. 1996). C. gibba, an introduced bivalve, had not been previously reported from the Derwent Estuary, although in Port Phillip Bay on mainland Australia, C. gibba is considered a major prey item of A. amurensis (G. Parry pers. comm.). In November 1997 and 1998, when all these species were rare, the seastar fed largely on the echinoid Echinocardium cordatum, the bivalves Theora spp. and Timoclea cardoides, polychaetes and crustaceans.

The observed shift in diet correlates with the ecological availability of prey. Bivalves such as Fulvia tenuicostata, Venerupis anomala, Corbula gibba and Timoclea cardoides are relatively accessible because they have short siphons, live just below the sediment surface and do not burrow deeply. In contrast, Theora spp. have long siphons and are likely to be less accessible to the seastar since they can live at depths several times their shell length (Willan 1998). Similarly, Echinocardium cordatum can remain deeply buried (up to $15 \mathrm{~cm}$, Buchanan 1966), maintaining contact with the surface by a funnel-like opening over its aboral side (Buchanan 1966). This requires that the seastar actively dig to access the prey. The complete absence of the bivalve Mysella donaciformis in the seastar diet is enigmatic. Possible explanations include escape by leaping movements and/or their very small size, which may decrease the probability of their detection and/or capture (Fukuyama \& Oliver 1985). Crustaceans are likely to be less available to seastars than bivalves due to their high mobility, while polychaetes may be less available because of behavioural avoidance (e.g. withdrawal into tubes). Interestingly, the majority of crustacean parts found in the stomach of Asterias amurensis in November 1997 were pieces of the crab Paragrapsis gaimardii. However, predation on this highly motile crab is likely to be incidental as a result of seastars preying on autotomised limbs or moults, both of which were abundant at the site during the survey. The clear pattern is that they eat the most accessible prey first, and shift to other less accessible prey only when availability of more accessible prey declines.

\section{CONCLUSIONS}

Bivalve populations in the Derwent Estuary are characterised by very small size and rarity of adults (Lockhart 1995, D. Ross pers. obs.). The presence in the surface sediments of the shells of large adults of several species suggests that this has not always been the case (Lockhart 1995, L. Turner pers. comm.). Experiments conducted outside the range of the seastar clearly demonstrated a major impact on adult bivalve populations, particularly the commercial bivalves Fulvia tenuicostata and Katelysia rhytiphora (Ross 2001). The results of this study showed that Asterias amurensis can have a large impact on the survivorship of juvenile bivalves, effectively arresting mass settlement events. Together, these results suggest that predation by $A$. amurensis may be largely responsible for the decline and subsequent rarity of adult bivalves in the Derwent Estuary. The observations of shifts in diet show that while the seastar has clear food preferences, it is a generalist predator able to consume other prey when preferred prey become rare. Thus, $A$. amurensis has the potential to impact a large variety of taxa and have wider effects on soft sediment communities than that demonstrated in short-term manipulative experiments. Our overall conclusion is that at the high densities that can occur in SE Tasmania, there are large direct effects on native assemblages, including commercial species such as F. tenuicostata. These important consequences of the establishment of this introduced predator warrant efforts to limit its impact.

Acknowledgements. We thank the many dive volunteers and co-workers without whose help this project would not have been possible, particularly Sarah Scott and Felicity McEnnaulty. A special thanks goes to Len Cusack for the countless number of days, help in the field. This manuscript benefited from discussions and comments from Alan Butler, Richard Martin and 3 anonymous reviewers. This work was supported by funds from the CSIRO Marine Research Centre for Research on Introduced Marine Pests (awarded to C.R.J.) and the School of Zoology, University of Tasmania. This work was undertaken as part of D. J. R.'s Doctor of Philosophy degree at the University of Tasmania who was supported by an Australian Postgraduate Award.

\section{LITERATURE CITED}

Anger K, Rogal U, Schriever G, Valentine C (1977) In situ investigations on the echinoderm Asterias rubens as a predator of soft-bottom communities in the western Baltic Sea. Helgol Wiss Meeresunters 29:439-459

Brenchley GA (1982) Mechanisms of spatial competition in marine soft-bottom communities. Biol Bull 60:17-33

Brenchley GA, Carlton JT (1983) Competitive displacement of native mud snails by introduced periwinkles in the New England intertidal zone. Biol Bull 165:543-558

Buchanan JB (1966) The biology of Echinocardium cordatum 
(Echinodermata: Spatangoidea) from different habitats. J Mar Biol Assoc UK 46:97-114

Buttermore RE, Turner E, Morrice MG (1994) The introduced northern Pacific seastar Asterias amurensis in Tasmania. Mem Queensl Mus 36:21-25

Byrne M, Morrice MG, Wolf B (1997) Introduction of the northern Pacific asteroid Asterias amurensis to Tasmania: reproduction and current distribution. Mar Biol 127: 673-685

Carlton JT, Geller JB (1993) Ecological roulette: the global transport of nonindigenous marine organisms. Science 261:78-82

Christensen AM (1970) Feeding biology of the sea star Astropecten Irregularis Pennant. Ophelia 8:1-134

Cohen AN, Carlton JT (1998) Accelerating invasion rate in a highly invaded estuary. Science 279:555-558

Coughanowr C (1997) State of the Derwent Estuary: a review of environmental quality data to 1997. Supervising Scientist Report 129. Supervising Scientist, Canberra

Dame RF (1996) Ecology of marine bivalves: an ecosystem approach. CRC Press, New York

Dayton PK (1971) Competition, disturbance, and community organization: the provision and subsequent utilization of space in a rocky intertidal community. Ecol Monogr 41: 351-387

Dayton PK, Oliver JS (1980) An evaluation of experimental analysis of population and community patterns in benthic marine environments. In: Tenore KR, Coull BC (eds) An evaluation of experimental analysis of population and community patterns in benthic marine environments. University of South Carolina Press, Columbia, p 93-120

Draper NR, Smith H (1981) Applied regression analysis. Wiley-Liss, New York

Edgar G J (1997) Australian marine life: the plants and animals of temperate waters. Reed Books, Kew, Victoria

Elton CS (1958) The ecology of invasions by animals and plants. Methuen, London

Fernandes TF, Huxham M, Piper SR (1999) Predator caging experiments: a test of the importance of scale. J Exp Mar Biol Ecol 241:137-154

Fukuyama AK, Oliver JS (1985) Sea star and walrus predation on bivalves in Morton Sound, Bering Sea, Alaska. Ophelia $24: 17-36$

Grannum RK, Murfet NB, Ritz DA, Turner E (1996) The distribution and impact of the exotic seastar, Asterias amurensis (Lütken), in Tasmania. In: The introduced northern Pacific seastar, Asterias amurensis (Lütken), in Tasmania. Australian Nature Conservation Agency, Canberra, p 53-138

Grosholz ED, Ruiz GM (1995) Spread and potential impact of the recently introduced European Green crab, Carcinus maenas, in central California. Mar Biol 122:239-247

Grosholz ED, Ruiz GM, Dean CA, Shirley KA, Maron JL, Connors PG (2000) The impacts of a nonindigenous marine predator in a California Bay. Ecology 81:1206-1224

Hall SJ, Raffaelli D, Turrell WR (1990) Predator-caging experiments in marine systems, a re-examination of their value. Am Nat 136:657-672

Hatanaka M, Kosaka M (1959) Biological studies on the population of the starfish, Asterias amurensis, in Sendai Bay. Tohoku J Agric Res 9:159-178

Hulberg LW, Oliver JS (1980) Caging manipulations in marine soft-sediment bottom communities, importance of animal interactions or sedimentary habitat modifications. Can J Fish Aquat Sci 37:1130-1139

Kim YS (1969) Selective feeding on the several bivalve molluscs by starfish, Asterias amurensis. Bull Fac Fish Hokkaido Univ 19:244-249
Lafferty KD, Kuris AM (1994) Potential uses for biological control of alien marine species. In: Cottingham D (ed) Nonindiginous estuarine marine organisms (NEMO). Proc Conf and Workshop, Seattle. NOAA, US Department of Commerce, p 97-102

Lambert WJ, Levin D, Berman J (1992) Changes in the structure of a New England (USA) kelp bed: the effects of an introduced species. Mar Ecol Prog Ser 88:303-307

Lockhart SJ (1995) Feeding biology of the introduced sea star, Asterias amurensis (Lütken) in Tasmania (Echinodermata Asteroidea). Honours Thesis, University of Tasmania, Hobart

Lockhart SJ, Ritz DA (1998) Feeding rates of the introduced sea star, Asterias amurensis (Lütken), in Tasmania. In: Mooi R, Telford M (eds) Proc 9th Int Echinoderm Conf, San Francisco. Balkema, Rotterdam, p 267-272

Lockhart SJ, Ritz DA (2001) Preliminary observations of the feeding periodicity and selectivity of the introduced seastar, Asterias amurensis (Lütken), in Tasmania, Australia. Pap Proc R Soc Tas 135:25-33

Lodge DM (1993) Biological invasions: lessons for ecology. Trends Ecol Evol 8:133-137

Menge BA (1972) Foraging strategy of a starfish in relation to actual prey availability and environmental predictability. Ecol Monogr 42:25-50

Menge BA (1982) Effects of feeding on the environment: Asteroidea. In: Jangoux M, Lawrence JM (eds) Echinoderm nutrition. Balkema, Rotterdam, p 521-551

Mills EL, Leach JH, Carlton JT (1993) Exotic species in the Great Lakes: a history of biotic crises and anthropogenic introductions. J Gt Lakes Res 19:1-54

Morrice MG (1995) The distribution and ecology of the introduced northern Pacific seastar, Asterias amurensis (Lütken), in Tasmania. In: The introduced northern Pacific seastar, Asterias amurensis, in Tasmania. Australian Nature Conservation Agency, Canberra, p 1-50

Newman JA, Bergelson J and Grafen AG (1997) Blocking factors and hypothesis tests in ecology: is your statistics text wrong? Ecology 78:1312-1320

Nichols FH, Thompson JK, Schemel LE (1990) Remarkable invasion of San Francisco Bay (California, USA) by the Asian clam Potamocorbula amurensis. II. Displacement of a former community. Mar Ecol Prog Ser 66:95-101

Nojima S (1989) Ecological studies on the sea star, Astropecten latespinosus Meissner. VI. Seasonal changes in stomach contents, preference of food items, size preference and two kinds of switching in feeding habits. Publ Amakusa Mar Biol Lab Kyushu Univ 10:17-40

Nojima S, Soliman FA, Kondo Y, Kuwano Y, Nasu K, Kitajima C (1986) Some notes of the outbreak of the sea star Asterias amurensis versiclor Sladen, in the Ariake Sea, western Kyshu. Publ Amakusa Mar Biol Lab Kyushu Univ 8:89-112

Ólafsson EB, Peterson CH, Ambrose WG Jr (1994) Does recruitment limitation structure populations and communities of macroinvertebrates in marine soft sediments: the relative significance of pre and post settlement processes. Oceanogr Mar Biol Annu Rev 32:65-109

Paine RT (1966) Food web complexity and species diversity. Am Nat 100:850-859

Paine RT (1974) Intertidal community structure: experimental studies on the relationship between a dominant competitor and its principal predator. Oecologia 15:93-120

Peterson CH (1980) Predation, competitive exclusion and diversity in the soft-sediment benthic communities of estuaries and lagoons. In: Livingston RJ (ed) Predation, competitive exclusion and diversity in the soft-sediment benthic communities of estuaries and lagoons. Plenum Press, New York, p 233-264 
Peterson CH, Black R (1993) Experimental tests of the advantages and disadvantages of high density for two coexisting cockles in a Southern Ocean lagoon. J Anim Ecol 62: 614-633

Posey MH, Wigand C, Stevenson JC (1993) Effects of an introduced aquatic plant, Hydrilla verticillata, on benthic communities in the upper Chesapeake Bay. Estuar Coast Shelf Sci 37:539-555

Race MS (1982) Competitive displacement and predation between introduced and native mud snails. Oecologia 54: 337-347

Robles C, Sherwood-Stephens R, Alvarado M (1995) Responses of a key intertidal predator to varying recruitment of its prey. Ecology 76:565-579

Ross DJ (2001) Impact of the nothern Pacific seastar Asterias amurensis on soft sediment assemblages, including commercial species, in southeast Tasmania. Department of Zoology, PhD dissertation, University of Tasmania, Hobart

Ross DJ, Johnson CR, Hewitt CL (in press) Assessing the ecological impacts of an introduced seastar: the importance of multiple methods. Biol Inv

Ruiz GM, Rawlings TK, Dobbs FC, Drake LA, Mullady T, Huq A, Colwell RR (2000) Global spread of microorganisms by ships. Nature 408:49-50

Sloan NA (1980) Aspects of the feeding biology of asteroids. Oceanogr Mar Biol Annu Rev 18:57-124

Editorial responsibility: Otto Kinne (Editor), Oldendorf/Luhe, Germany
Thrush SF (1986) Community structure on the floor of sealough: are large epibenthic predators important? J Exp Mar Biol Ecol 104:171-183

Thrush SF (1999) Complex role of predators in structuring soft-sediment macrobenthic communities: implications of changes in spatial scale for experimental studies. Aust J Ecol 24:344-354

Thrush SF, Hewitt JE, Pridmore RD, Cummings VJ (1996) Adult/juvenile interactions of infaunal bivalves: contrasting outcomes in different habitats. Mar Ecol Prog Ser 132: $83-92$

Todd CD, Keough MJ (1994) Larval settlement in hard substratum epifaunal assemblages: a manipulative field study of the effects of substratum filming and the presence of incumbents. J Exp Mar Biol Ecol 181:159-187

Vanderplog HA, Scavia D (1979) Two electivity indices for feeding with special reference to zooplankton grazing. J Fish Res Board Can 36:362-365

Virnstein RW (1978) Predator caging experiments in soft sediments: caution advised. In: Wiley ML (ed) Estuarine interactions. Academic Press, New York, p 261-273

Vitousek PM (1994) Beyond global warming-ecology and global change. Ecology 75:1861-1876

Willan RC (1998) Superfamily Tellinoidea. In: Beesley PL, Ross GLB, Wells A (eds) Fauna of Australia, Vol 5, Mollusca: the Southern Synthesis. CSIRO Publishing, Melbourne, p 342-348

Submitted: August 27, 2001; Accepted: April 18, 2002 Proofs received from author(s): September 6, 2002 